\title{
ПРИЛАГАНЕ НА КОНВЕНЦИЯТА НА ЮНЕСКО ЗА ОПАЗВАНЕ НА НЕМАТЕРИАЛНОТО КУЛТУРНО НАСЛЕДСТВО 2003 ГОДИНА НА НАЦИОНАЛНО НИВО: БЪЛГАРСКИЯТ ОПИТ
}

\section{М. Сантова}

\begin{abstract}
Сантова М. Прилагане на Конвенцията на ЮНЕСКО за опазване на нематериалното културно наследство 2003 година на национално ниво: българският опит. В годините около и последвали непосредствено акта на приемането от Генералната конференция на ЮНЕСКО през 2003 г. на Конвенцията за опазване на нематериалното културно наследство (Конвенция 2003) България натрупа опит в подготовката и формулирането на културни политики и дейности, свързани с прилагането на директивите за опазване, които Конвенцията чертае. В текста се говори за предприетите от България мерки: културни политики, програми и субекти по прилагане на Конвенцията.
\end{abstract}

Ключови думи: нематериално културно наследство, България, Конвенция 2003, читалища.

Сантова М. Применение Конвенции ЮНЕСКО для охраны нематериального культурного наследия ЮНЕСКО 2003 года на национальном уровне: болгарский опыт. В годы накануне и после принятия Генеральной конференцией ЮНЕСКО 2003 г. Конвенции по охране нематериального культурного наследия (Конвенция 2003) Болгария накопила опыт в подготовке и формулировании культурных политик, а также деятельности, связанной с применением директив по охране, очерченных Конвенцией. В тексте речь идет о предпринятых Болгарией мерах: культурных политиках, программах и субъектах имплементации Конвенции.

Ключевые слова: нематериальное культурное наследие, Болгария, Конвенция 2003, читалишта.

Santova M. Implementing at National Level the 2003 UNESCO Convention on the Safeguarding of The Intangible Cultural Heritage: The Bulgarian experience. During the years coinciding in time with, and immediately following, the act of the adoption in 2003 by the UNESCO General Conference of the Convention on the Safeguarding of the Intangible Cultural Heritage ('the 2003 Convention') Bulgaria has accumulated considerable experience in the preparation and formulation of cultural policies and activities pertinent to the application of the provisions and guidelines of the convention. The text speaks of the measures undertaken in Bulgaria: Cultural policies, Programmes and Subjects for implementation to convention.

Keywords: Intangible Cultural Heritage, Bulgaria, Convention 2003, chitalishta.

During the years coinciding in time with, and immediately following, the act of the adoption in 2003 by the UNESCO General Conference of The Convention on the Safeguarding of the Intangible Cultural Heritage (The 2003 Convention), Bulgaria has accumulated considerable experience in the preparation and formulation of cultural policies and activities pertinent to the application of the provisions and guidelines of the convention. In some areas, what this country has done in this respect has been a pioneering accomplishment preceding international efforts.

Above all, since a very early stage Bulgaria had been making efforts to get the bearers of the intangible cultural heritage (ICH) actively involved in the processes of its preservation and safeguarding. In this context, Bulgaria has the unique advantage of having a network of institutions, the so-called chitalishta, a type of community centre with over a hundred years of history. Such community centres, which exist in practically every populated area across the country, are in their majority, for all intents and purposes, civic associations constituted on a territorial principle (in accordance with a special Act of Parliament that governs their operation) of practitioners of skills and knowledge in the area of ICH. Thus the involvement of the chitalishta in the policies for the safeguarding of ICH provides a direct link between those policies and the largest possible number of practitioners from around the country.

$$
* * *
$$

There are several key activities in the area of the intangible cultural heritage that Bulgaria has been pursuing since the time preceding or directly following the adoption of The 2003 Convention:

(C) Сантова, М., 2016 
- Bulgaria was among the very first countries in the world to have prepared and officially established a National Inventory of The Intangible Cultural Heritage, the compilation of which coincided in time with the drafting of the final texts of The 2003 Convention.

- In 2006, a National Council for The Intangible Cultural Heritage was set up under the Minister of Culture, as the body responsible for coordinating at national level all work pertinent to the safeguarding of ICH in Bulgaria.

- In 2007, Bulgarian experts initiated the establishment of a Regional Network of Experts in Intangible Cultural Heritage from the Region of South-Eastern Europe. Initially that expert network, which turned out to be the first of its kind in the world, was supported by the UNESCO Bureau in Venice, the Bulgarian Ministry of Culture and the National Commission for UNESCO in Bulgaria, and since 2012, by the Regional Centre for the Safeguarding of the Intangible Cultural Heritage Cat. 2, based in Sofia.

- Towards the end of 2007, this country launched the National Programme for Living Human Treasures of Bulgaria; in June 2008 that National Programme made the first five national nominations, which became the first five inscriptions on the National Representative List of Elements of the Intangible Cultural Heritage. Through its subsequent editions (held in every even year after 2008), the National Programme has established itself as a key cultural policy of Bulgaria in the area of the intangible cultural heritage: National System of Living Human Treasures of Bulgaria. And, although it 'borrows' its title from practices related to the preservation of the legacy of other cultures and traditions, the Bulgarian System has its own meaningful aspects, related to the building of a National Representative List of Elements of the Intangible Cultural Heritage, analogous to the World Lists. Every other year, another five elements are inscribed on the National List through the practices of operation of the System.

- On February $20^{\text {th }}, 2012$, Sofia saw the inauguration of the Regional Centre for the Safeguarding of the Intangible Cultural Heritage Category 2, under UNESCO auspices. The Centre covers the entire region of South-Eastern Europe and is the first of its kind on the European continent.

- The National Centre for the Intangible Cultural Heritage is located at the Institute of Ethnology and Folklore Studies with Ethnographic Museum of the Bulgarian Academy of Sciences. The Institute also operates an Expert Council for the Intangible Cultural Heritage, which works in close connection with the National Centre.

- Bulgaria also maintains in its territory two Local Centres for the Intangible Cultural Heritage: at the villages of Bistritsa and Bulgari. Other populated areas have also shown an interest in having their own local ICH centres.

\section{Cultural policies, Programmes, Authorities}

The Bulgarian National Inventory of the Intangible Cultural Heritage was created by a team of the Institute of Folklore of the Bulgarian Academy of Sciences ${ }^{1}$ with the participation of the Ministry of Culture of the Republic of Bulgaria and the regional and local administrative structures under its jurisdiction active in the field of culture, and with the support of the National Committee for UNESCO. Also instrumental in compiling the Inventory has been the National Network of Bulgarian Community Centres (chitalishta). The involvement of the three types of institutions meant, in practical terms, the integration of three types of entities in the definition of activities and the production of the Register, all of special significance in principle for formulating the procedures of safeguarding the intangible cultural heritage $(\mathrm{ICH})$ :

a) the State;

b) the experts;

c) practitioners (bearers) and reproducers of ICH: communities, groups of people or individuals, as well as non-governmental organisations (pursuant to the 2003 Convention). As was already mentioned, in the case of Bulgaria such non-governmental organisations - the chitalishta - are predominantly structured on a territorial principle and largely collocate with the practitioners of $\mathrm{ICH}$, whether communities, groups or individuals.

The Bulgarian National Inventory for the Intangible Cultural Heritage was created in 20012002. On the one hand, its preparation coincided in time with the final polishing of the drafts for the 2003 Convention itself. On the other, however, this also meant that when Bulgaria began work on its Inventory, there had been no prior international experience in this type of undertaking. 
Towards the end of 2002, the Inventory was officially recognised and adopted by the Bulgarian State, represented by the then Minister of Culture. The Bulgarian National Inventory turned out to be the first of its kind in Europe, preceding by about a year the official adoption of the 2003 Convention by the UNESCO General Conference, whose Art. 12 explicitly calls for the establishment of such registers as part of the procedures for safeguarding the intangible cultural heritage at national level.

Thus, by creating its National Register at the dawn of the $21^{\text {st }}$ century, Bulgaria turned out to be one of the first nations worldwide to have fulfilled the provision of Art. 12 of the Convention.

The Bulgarian National Inventory defines several spheres where cultural activities of different types are organised. While these reflect the areas of manifestation of ICH as identified in Art. 2 of the 2003 Convention, the way they are formulated in the Bulgarian Register accounts for the specific forms of ICH in Bulgarian territory.

The official delivery of the thus completed Register to the Minister of Culture in the fall of 2002 was a symbolic act through which the Bulgarian State formally adopted that important document as its own. Placed in perspective, this means that the State undertakes as one of its primary concerns in safeguarding ICH the delicate mission of ensuring the ability of people to pass on to the next generation the requisite competences, whether as practitioners or experts, for keeping alive the elements of the intangible cultural heritage that the State has explicitly recognised by entering them into the Register.

Today, the Bulgarian National Inventory of the Intangible Cultural Heritage is published on the official website of the Ministry of Culture of the Republic of Bulgaria (http://www.treasuresbulgaria.com/).

$$
* * *
$$

The establishment in 2006 of a National Council for the Intangible Cultural Heritage under the Minister of Culture (as the successor to the previously existing National Folklore Council) came in direct pursuance of Art. 43 (1) of The Bulgarian Cultural Heritage Act. According to the official documents, this body aims to:

- support the development of a strategy for safeguarding and promotion of the traditional Bulgarian culture and folklore;

- propose measures for the implementation of international instruments in the area of ICH to which Bulgaria is a party;

- propose measures for improving the systems of safeguarding the intangible cultural heritage;

- make recommendations on matters of the safeguarding, conservation and promotion of the intangible cultural heritage;

- propose to The Minister of Culture, for his/her approval, elements of ICH to be inscribed on the National Representative List of the Intangible Cultural Heritage.

Pursuant to the Rules on the Composition, Functions and Operation of the National Council for ICH under the Minister of Culture (promulgated in State Gazette, No. 45/May 18 ${ }^{\text {th }}, 2013$ ), the Council may be chaired by the competent Deputy Minister and comprise as its members experts in various ICH fields, ICH practitioners, members of civic organisations and specialised institutions in the area of $\mathrm{ICH}$, and a representative each of The Ministry of Culture and the National Commission for UNESCO.

$$
* * *
$$

In 2007, Bulgaria initiated the organisation of, and played host to, a Seminar for Experts in the field of the intangible cultural heritage in South-Eastern Europe. This Seminar was designed, on the one hand, to serve as a working forum for the exchange of experience and good practices between the countries in the region, and on the other, to help familiarise experts from different countries with the accomplishments of Bulgaria, its experts and institutions, in the relevant field thus far. Taking part in the seminar were experts from 9 countries in South-Eastern Europe: Albania, Bosnia and Herzegovina, Bulgaria, Croatia, Cyprus, Macedonia, Romania, Slovenia, and Turkey. The participants unanimously pointed to the need to establish a permanent working forum of experts from this part of Europe, which led them to the idea for setting up a Network of Experts in the field of the intangible cultural heritage for South-Eastern Europe.

Thus, in 2007, the historic village of Arbanassi, in northern Bulgaria, hosted the inauguration of the first Network of ICH Experts in the whole world, that for South-Eastern Europe. In 
the years that followed, the Network began to operate by holding annual meetings, hosted each time by a different country in the region. Today, the institution in charge of that Network is the Regional Centre for the Safeguarding of the Intangible Cultural Heritage Cat. 2, based in Sofia.

$$
* * *
$$

The National System of Living Human Treasures of Bulgaria was launched as a project in directly relation to the UNESCO-sponsored pilot programme of Living Human Treasures, which was adopted as a national programme and subsequently established as a national system.

The National System of Living Human Treasures of Bulgaria (http://mc.government.bg/reg/ index.php?act $=$ content $\& d o=$ detailed $\& \mathrm{rec}=670$ ) provides an opportunity for this country to propose, once every two years, nominations in the field of $\mathrm{ICH}$, mostly initiated by the chitalishta (community centres), or by regional museums, with the support of local structures in the cultural field. The Bulgarian system, while based on the eponymous pilot project launched by UNESCO, has certain specificities; among the most significant of those is the fact that its biennial sessions result in inscriptions on the National Representative List of Elements of the Intangible Cultural Heritage. Pursuant to the established rules, the nominations must be of elements already listed in the National ICH Register. In the nomination form especially developed for the purpose by the experts, there is a field where the nominating body must state the field (sphere) of ICH as per the National Register within whose parameters the nomination is made. Also, the express consent of the practitioners of the ICH element in question is required.

The system provides for two rounds of selection: a regional and a national one. In the first round, 28 nominations are made, one for each of the 28 administrative districts of Bulgaria (the country's administrative division is used as a reference framework to facilitate coordination procedures at national level). This is followed by a second round, which shortlists 5 nominations, all of which are inscribed on the National Representative List of Elements of the Intangible Cultural Heritage.

The conferral of diplomas on the five selected ICH elements carries material incentives, provided by the State, for their practitioners. According to a practice established already with the earliest inscriptions, these are cash disbursements aimed primarily at facilitating the transmission of the element. The cheques are officially handed to the winning entrants by the Minister of Culture or an official especially designated by him/her.

The selection is carried out by panels of judges, composed on a regional basis, appointed by an order of the Minister of Culture. Such panels comprise each an expert of the Institute of Ethnology and Folklore Studies with Ethnographic Museum under the Bulgarian Academy of Sciences, a local expert, a member of the local community centre (chitalishte) and/or regional museum, as well as representatives of the local cultural authorities. The national panel of judges is made up of experts of the National Centre for the Intangible Cultural Heritage.

The above described selection process and judges notwithstanding, the National System of Living Human Treasures itself is not competitive in nature. To the Bulgarian State, the entire sphere of the intangible cultural heritage of its population is of great value and concern. Such selections and inscriptions are, in fact, a sign of the State's concern in making sure that the heritage that belongs to all of its citizens could be preserved in perpetuity.

Inscriptions on the National Representative List of Elements of the Intangible Cultural Heritage serve as an incentive for local communities to ensure their proper transmission, without involving any brutal official interference into the core essence of such processes, as pursued naturally by the bearers.

\section{Structures and Centres}

Bulgaria maintains a range of specialised centres operating in the sphere of the intangible cultural heritage at regional, national, and local level.

$$
* * *
$$

The Regional Centre for the Safeguarding of the Intangible Cultural Heritage under UNESCO Auspices. On October $25^{\text {th }}, 2010$, at a special ceremony at the UNESCO HQ in Paris, the Minister of Culture of Republic of Bulgaria and the UNESCO Director General signed an Agreement on the Establishment in Sofia of a Regional Centre for the Safeguarding of the Intangible Cultural Heritage in South-Eastern Europe. 
On March $16^{\text {th }}, 2011$, The National Assembly passed a Law on the Ratification of the Agreement between the Government of the Republic of Bulgaria and the United Nations Education, Science and Culture Organisation (UNESCO) on the establishment on Sofia (Bulgaria) of a Regional Centre for the Safeguarding of the Intangible Cultural Heritage in South-Eastern Europe under UNESCO Auspices (Category 2) (http://bg.unesco-centerbg.org/view/post/32)

Pursuant to its Statute,

Art. 6. The Objectives of the Centre are to:

1. Promote the UNESCO Convention for the Safeguarding of the Intangible Cultural Heritage and contribute to its implementation in the South-Eastern European sub-region;

2. Increase the participation of separate communities, groups and individuals in safeguarding intangible heritage in the South-Eastern European countries;

3. Enhance the capacity of the Member States in UNESCO from South-Eastern Europe in safeguarding the intangible cultural heritage;

4. Coordinate, exchange and disseminate information regarding the safeguarding of intangible cultural heritage in the sub-region;

5. Foster regional and international cooperation for safeguarding intangible cultural heritage;

6. Support the efforts for safeguarding of the elements of intangible cultural heritage from the region that are included in the UNESCO Representative List of Intangible Cultural Heritage and the UNESCO List of Intangible Cultural Heritage in Need of Urgent Safeguarding;

7. Support and assist the countries from the region in the processes of identifying and inventorying the intangible cultural heritage and in developing systems at the national level for recognizing the intangible heritage present in their territories;

8. Cooperate with the institutions engaged in studying and safeguarding the intangible cultural heritage on a local, national and regional level as well as for establishment of relations between them;

9. Support and participate in activities for training of specialists in the field of intangible cultural heritage;

10. Make efforts for strengthening the cooperation with UNESCO and the respective related institutions in other countries and regions (http://bg.unesco-centerbg.org/files/f279dfde882b4c1f6288e428293882e4.pdf).

$$
* * *
$$

The National Centre for Safeguarding of the Intangible Cultural Heritage, which has its seat at the Institute of Ethnology and Folklore Studies with Ethnographic Museum under The Bulgarian Academy of Sciences operates in close connection with the Expert Council of the Intangible Cultural Heritage at the same Institute.

The National Centre for the Intangible Cultural Heritage (NC ICH) collects, processes and stores documents describing, or otherwise related to, elements of ICH as well as other documents. It assists in the implementation of the National System of Living Human Treasures of Bulgaria by storing the documentation of relevance to it. The National Centre provides methodological assistance for the operation of the Local Centres for the Intangible Cultural Heritage.

\section{Local Centres for the Intangible Cultural Heritage at the villages of Bistritsa and Bulgaria.}

The local centres presently existing in the territory of Bulgaria were established (as was the case with the village of Bistritsa) by a three-way agreement between the Ministry of Culture (MC) of the Republic of Bulgaria, the relevant research institution of the Bulgarian Academy of Sciences and members of the local community. Practice has shown that in Bulgaria's cultural reality, those are the chairpersons of the chitalishta boards of trustees. Pursuant to the tree-way agreement, the functions in that partnership are distributed as follows: MC provides administrative support and supervision; BAS provides methodological assistance; and the local authority plays host and manages the day-to-day affairs of the centre. In the case of the village of Bulgaria, the local centre has the status of an affiliate body of the Georgi Kondolov chitalishte in the town of Tsarevo (the town being a municipal centre).

${ }^{1}$ Since 2010, following its merger with the BAS, Ethnographic Museum, this is known as the Institute of Ethnology and Folklore Studies with Ethnographic Museum (IEFSEM) of The Bulgarian Academy of Sciences (BAS). 